\title{
ARQUITECTURAS INVISIBLES
}

\section{A}

RESUMEN El concurso siempre ha sido una herramienta de investigación necesitada de una puesta al dia de los conocimientos:

"E n la película Blow Up de M. Antonioni, un fotógrafo, para compensar la violencia y el dolor - inherente a un reportaje que ha hecho sin sentir la más mínima implicación, va a hacer fotos al ambiente sosegado de un parque de estilo inglés, apacible y poco transitado. Al hacer fotos de un pareja que aparece a lo lejos, la única que pasea por el parque, se encuentra luego al ampliarlas con que su cámara ha captado un misterioso asesinato, que insiste en involucrarlo a él. En la ampliación de las fotos descubre que oculto en el denso follaje de un seto aparece la silueta de un hombre y sobresale una mano que apunta con una pistola. Y en la secuencia siguiente comprueba que incluso aparece un cadáver. Sus imágenes son pruebas contundentes. Sin embargo, él no ha visto nada, el Ediciones Ardora, 2007, p. 21.

Proponer un número de un tánea de un tema en la que el enfoque captura ideas buscadas y también otras desconocidas. Cualquier acto creativo nos obliga a hacer una reliexión sobre el valor de lo invisible. Justificamos nuestras decisiones porque deseamos que sean intencionadas, claras, evidentes, que persigan un objetivo y, con esos parametros, surge la propuesta de un tema. Es el momento de lo visible, de la evidencia Posteriormente cuando recibimos la respuesta se manifiesta otra dimnensión invisible del proyecto y la eficacia de nuestra demanda queda circunscrita a lo imprevisible de las respuestas, de lo que nunca estuvo visible en nuestras mentes. En el futuro alguien releerá esta paginas que hoy están escritas en un contexto, y este presente se sumergirá en el olvido que impone el tiempo y estos textos vivirán latentes en el reposo al que serán sometidos en los estantes de las biblotecas para de nuevo verificarse, renaciendo, haciendose visible sôlo aquello que en el silencio mantenia un valor. Todo lo que hoy se diga y caduque resultará olvidado.

El concurso de arquitectura es la oportunidad de promotores públicos y privados para confrontar diferentes posibilidades de actuación o soluciones sobre un territorio concreto, entendiendo que el territorio del proyecto arquitectónico abarca desde el planeamiento a gran escala, al proyecto urbano. a la rehabilitación, al mobiliario urbano, e incluso, un largo etcétera de otras áreas próximas al proyecto arquitectónico, donde el concurso se impone como la mejor plataforma de confrontación de ideas en el ensayados para conseguir que el concurso sea un medio adecuado para reunir a pensadores -cada 

vez más, provenientes de diferentes campos participando en equipos multidisciplinares- sobre espa-
cios candidatos a ser transformados y presentar una respuesta necesaria a los modos de vida que la sociedad demanda en un contexto temporal de actualidad.

Una de las razones de las revistas de arquitectura siempre ha sido dar difusión a los resultados de los concursos, En los inicios de la revista Arquitectura, la sección de "Arquitectura Española Contemporánea" se dedicó a la difusión de los principales concursos que se convocaban en España, siguiendo la tradición del Boletín de la Sociedad Central de Arquitectos, de la Revista de la Arquitectura Nacional y Extranjera, de los Anales de la Construcción y la Industria, del Anuario de la Asociación de Arquitectos de Cataluña, o de la revista Arte y Construcción, que marcan un periodo que transcurre desde mediados del siglo XIX hasta el primer cuarto del siglo XX. Se trata del germen de un espiritu que se debiera haber desarrollado hasta nuestros dias. No obstante, muchas de las actuales revistas se han entregado a criterios editoriales más comerciales que crtiticos, en el comodo cauce de la información brindada por los fotografos de arquitectura en las dos ultimas décadas, que como oteadores han vendido su trabajo sustituyendo la figura del crítico de arquitectura.

El concurso siempre ha sido una herramienta de investigación necestlada de una puesta al día de los conocimientos. difundiendo los logros alcanzados se muestra también la exigente actualización del arquitecto de una manera integral. No todos los concursos son iguales, ni pretenden los mismos objelivos y en un gran número, desgraciadamente, han servido de camullaje a cuestiones que van más allá de la calidad. Intereses politicos o comerciales tienden a confundir la oportunidad de la difusión con la bondad del proyecto. Sería posible enumerar numerosos concursos que en el último siglo han supuesto un avance significativo en la arquitectura, una cierta anoranza de aquellos tiempos de debate que, junto a otras formulas proximas -bienales, trienales o exposiciones internaciones-, eran capaces de hacer investigación empirica desde la practica directa. Hoy, por el contrario, a menudo, el marco de actuación del proyecto arquitectónico se define de una manera ajena a la propia arquitectura, administrativamente dominado por un proceso que prima el cumplimiento legal y técnico frente a la calidad del propio proyecto, confundiendo el medio con el fin. La critica apunta siempre al autor; se olvidan los excelentes procedimientos que armaron a un jurado exonerado de responsabilidad de manera gratuita o ese marco legal que tanto astixia a la arquitectura en contra del espiritu investigador que siempre debiera prevalecer

Este número se plantea como la asimilación del concurso a un proceso de investigación paralelo a una arquitectura unida a la calidad y el progreso, una arquitectura avanzada. A pesar ello, muchos han visto en este procedimiento la manera de justificar lo injustificable y bajo la cobertura del concurso ocultar las más poversas decisiones, pero en el fondo no podemos negar que es el procedimiento de más calidad y más abierto que permite pensar en el progreso de la arquitectura. Esta fórmula abre las puertas a que cualquiera pueda ofrecer planteamientos alternativos sobre las demandas iniciales del concurso lo que en algunos casos ha significado importantes beneficios. En las ultimas decadas, a través de este método, se ha generado una valiosa arquitectura, de escala media y pequeña que ha dotado a muchos municipios de edificios públicos y viviendas permitiendo construir nuevos escenarios para nuestras vidas cotidianas.

En este momento quisieramos comprender la realidad del concurso desde los dos extremos que se ponen en relación, el del promotor y del arquitecto, en la medida de que es la fórmula más eficaz de ofrecer alternativas a un planteamiento y en ese sentido no cabe otra conclusión que su consideración como investigación.

Uno de los momentos donde la arquitectura culta se hace presente es el concurso. Quien convoca un concurso es porque requile de una solucion que no está presente en el repertorio conocido. Quien se presenta a un concurso es porque tiene la pretension de conseguir un proyecto novedoso, original, que pueda aportar un avance en las ideas" (Torrent, Horacio. "Arquitectura culla. anotaciones en los márgenes". En ARQ n. 50 Santiago mar 2002, Pontificia Universidad Católica de Chile, Escuela de Arquitectura, p. 10).

Incluso una vez cerrado el contenido de este número de la revista, surgen mil preguntas aún sin respuesta y que deberan abrir un debate constante hasta que se estabilice este presente caótico del que somos victimas y al que esperemos que este número aporte una cierta lilusion, y si no es así, al menos que el generoso y gratuito trabajo que desarrollamos trasciende a nosotros mismos, a nuestros tiempos.

Una cantidad incontable de arquitectos acude a cada concurso convocado generando miles de propuestas diversas, ganadoras o no, guardadas en los archivos que reflejan la socialización de la profesión del arquitecto, pero tambiên su masificaciôn, provocando que el arquilecto esté dispuesto a todo, a regalar su trabajo a cambio de soñar con ser arquitecto. En el seminario sobre La Divulgación de los Concursos de Arquilectura como Herramienta de Formación" celebrado en 2012 en la Escuela de Arquitectura de Sevila, todos los ponentes coincidieron que haciendo trabajar tanto a tantos arquitectos, al menos se deberían publicar y difundir todas las propuestas. Resulta sorprendente que algunas se repitan, concurso a concurso, hasta que resultan ganadora. Es necesario admitir que podemos encontrar un enorme interés en las propuestas que sin ser ganadoras, nos dejan una lección de arquitectura... Una enorme desconfianza sobre los jurados... que dijo que iba a hacertas que sin ser ganadoras dejan una lecciconscurso ahasta En un concurso siempre debemos estar preparados, como en una novela de suspense, a que nos sorprenda una propuesta no esperada y que hemos de saber valorar; a esa lección novedosa de arquitectura; a un avance, un paso adelante de la mano más anónima, a pesar de que su resultado se convierta en una Arquitectura Invisible. 